\title{
An Analysis of Foreign Direct Investment (FDI) and Economic Growth: Empirical Results from Nigeria
}

\author{
Damina Hamid Babawulle \\ Department of Economics, Faculty of Social and Management Sciences, Bauchi State University, Gadau, \\ Nigeria. \\ Email: hamid.db32@gmail.com
}

\begin{abstract}
In theory Foreign Direct Investment (FDI) is believed to have several positive relationship with the economic growth of the host country (such as productivity gains, technology transfers, the introduction of new processes, managerial skills and know - how, employee training) and in general it is a significant factor in modernizing the host country's economy and promoting its growth. It is in this light that this paper offered to take the impact of FDI on Nigeria's economic growth. Using annual data over the period 1981 to 2014, this study examines the contributions of FDI to Nigeria's economic growth. Employing an unrestricted vector autoregressive model (VAR), empirical estimates showed that over the period of analysis, FDI had a negative influence on economic growth in the country. This is contrary to the theories highlighting the importance of improving trade openness giving FDI inflows a prominent role in the development strategy of a country.
\end{abstract}

Keywords: Foreign Direct Investment, Economic Growth, Empirical, Vector Autoregressive

DOI: $10.7176 / \mathrm{JESD} / 11-8-16$

Publication date: April $30^{\text {th }} 2020$

\section{Introduction}

Foreign Direct Investment (FDI) is an investment made to acquire a lasting management interest (normally $10 \%$ of voting stock) in a business enterprise operating in a country other than that of the investor defined according to residency (The World Bank, 2015). FDI has been defined as the investment of resources in business activities outside a firm's home country (Hill, 2010). Jorgenson, (2007) defines Foreign Direct Investment as the process whereby people in one country obtain ownership of assets for the purpose of gaining control over the production, distribution and other activities of a firm in a foreign country.

Most countries strive to attract foreign direct investment (FDI) because of its acknowledged advantages as a tool of economic development. Africa and Nigeria in particular, joined the rest of the world in seeking FDI as evidenced by the formation of the New Partnership for Africa's Development (NEPAD), which has the attraction of foreign investment to Africa as a major component. Undoubtedly Africa and indeed Nigeria is facing a situation of economic crisis, featured by recession, inadequate resources for long - term development, high poverty level, low capacity utilization, high level of unemployment, and other macroeconomic objectives increasingly becoming difficult to achieve. Promoting and facilitating technology transfer through foreign direct investment (FDI) has assumed a prominent place in the strategies of economic revival and growth being advocated by policy makers at the national, regional and international levels because it is considered to be the key to bridging the technology and resource gap of underdeveloped countries and avoiding further build-up of debt (UNCTAD, 2012). 
Given this development, Ikiara, 2011; UNCTAD, 2014 recognize and emphasize the significance of FDI in providing technological know- how, capital, management and marketing skills, facilitating access to foreign markets and generating both technological and efficiency spillovers to local firms provided the right policy and business conditions are available. By facilitating access to the above, FDI is expected to improve the integration of the Nigeria's economy into the global economy, and further spurring economic growth through technological advancement.

The process of economic growth is a highly complex phenomenon and is influenced by numerous and varied factors such as political, social and cultural factors. As such economic analysis can provide only a partial explanation of this process. "Economic development has much to do with human endowments, social attitudes, political conditions and historical accidents. Capital is a necessary but not a sufficient condition of progress" Prof. Ragnar Nurkse.

In the face of inadequate resources to finance long-term development in Africa and increasing level of poverty, attracting FDI assumed a prominent place in the strategies of African countries. It is argued that, Africa entirely is suffering from poor governance, war and violence. To overcome the constraints on productivity, government need to improve their countries' investment climate in order to increase opportunities and incentives for enterprises both domestic and foreign to invest productively (Sachs \& Snowdon, 2013).

There are four basic requirements for economic growth and development which include: investment capital, technical skills, enterprise and natural resources. Without the mentioned component above in adequate proportions economic growth is a dream, (Shiro, 2011). The provision of the first three requirements (i.e. investment capital, technical skills, and enterprise) presents problem to Nigeria. This is due to the low level of income which prevent the mobilization of adequate savings needed to stimulate investment capital at home and finance training in modern production techniques and investment methods, (Shiro, 2011).

For any country (Nigeria in particular) with this saving-investment gap, foreign capital is regarded as an alternative to bridge the gap (Adofu \& Ilemona, 2010). So, FDI is seen as an antidote for slow rate of economic growth which the country has been experiencing (World Bank, 2011). Hence, this paper, aim at finding out the impact of FDI on economic growth in Nigeria. The research will answer the following research questions:

i) What is the relationship between Foreign Direct Investment (FDI) and economic growth in Nigeria?

ii) What is the effect of domestic saving and investment on economic growth in Nigeria?

The objective of this study therefore, is to analyze the impact of Foreign Direct Investment (FDI) on economic growth in Nigeria, specifically determine the effect of domestic saving and investment on economic growth in Nigeria. For this purpose, the paper is divided into four sections. The first section is the introduction, the second section is the theoretical framework and Literature Review, the third section is the methodology, the fourth section discusses the result of the study and the fifth section concludes the work.

\section{Literature Review}

The empirical evidence on FDI and economic growth is ambiguous, although in theory FDI is believed to have several positive relationship with the economic growth of the host country (such as productivity gains, technology transfers, the introduction of new processes, managerial skills and know - how, employee training) and 
in general it is a significant factor in modernizing the host country's economy and promoting its growth. It is believed that FDI can contribute to the economic development of the host country. Hence, we focus on this subject in our present study to investigate further the relationship between FDI and the host country's growth particularly Nigeria.

\section{Theoretical Literature Review}

\section{Solow Type Growth Theory}

The role of foreign direct investment (FDI) in stimulating economic growth is one of the controversial issues in the development literature. In the standard Solow type growth model, FDI enables host countries to achieve investment that exceeds their own domestic saving and enhance capital formation. According to this theory, the potential beneficial impact of FDI on output growth is confined to the short run. In the long run, given the diminishing marginal returns to physical capital, the recipient economy could converge to the steady state growth rate as if FDI had never taken place leaving no permanent impact on the growth of the economy (Mello \& Fukasaku, 2000).

Mankiw, (2010) applying the Solow growth model argues that private businesses invest in traditional types of capital such as bulldozers and steel plants and newer types of capital such as computers and robots. On the other hand, government invests in various forms of public capital, called infrastructure, such as roads, bridges and sewer systems. Mankiw further argues that policy makers trying to stimulate growth must confront the issue of what kinds of capital the economy needs most. In other words, what kind of capital yields the highest marginal products?

\section{Endogenous Growth Theory}

On the other hand, endogenous growth models e.g. Romer, (1986) that highlighted the importance of improvement in technology, efficiency, and productivity suggest that FDI can positively influence the growth rate in so far as it generates increasing returns in production via externalities and production spillovers. Endogenous growth model theory explained that physical investment is not a measure of economy growth of a country but the effectiveness and efficiency in the use of these investments. Economic models of endogenous growth have been applied to examine the effects of FDI on economic growth through the diffusion (outflow) of technology (Barro, 1991). Romer, (1986) argues that FDI propels economic growth through strengthening human capital, the most essential factor in Research and Development (R\&D) effort; while (Grossman \& Helpman, 1991) emphasize that an increase in competition and innovation will result in technological progress and increase productivity and, thus, promote economic growth in the long run. From the analyses made under this theory, it can be discovered that the theory suggests a better relationship between the FDI and economic growth of the developing countries.

\section{Two Gap Model}

According to two-gap model, external finance (loans, grants and FDI etc) can play critical role in supplementing domestic resources in order to relieve savings or foreign exchange bottlenecks. The basic argument of the two-gap model is that, most of developing countries face a shortage of domestic savings to match investment opportunities 
to finance needed imports of capital and intermediate goods. A country with a shortage of savings is unable to divert purchasing power from consumption goods to capital goods, either bought domestically or from abroad. As a result, excess foreign exchange may be spent on the importation of luxury consumption goods. Most developing countries however, are assumed to fall into the second category, where the foreign exchange gap is binding (Todaro \& Smith, 2009).

The savings-gap; starting with identity that, capital inflows (the difference between imports and exports) add to investable resource (domestic savings), the saving-investment gap is written as:

$$
\mathrm{I} \leq \mathrm{F}+\mathrm{sY}
$$

Where $\mathrm{F}$ is the amount of capital inflow, and if capital inflows (F) plus domestic savings (sY) exceed domestic investment (I) and the economy is at full-capacity, then a savings-gap is said to exist (Todaro \& Smith, 2009). The mechanisms of economic growth and development, therefore, are simply a matter of increasing national savings and investment. The main obstacle to growth and development according to this theory is the relatively low level of new capital formation in most poor countries. This obstacle can be solved by attracting more and more foreign direct investment (FDI) in order to fill up the gap (Todaro \& Smith, 2009).

\section{Empirical Literature Review}

Foreign direct investment (FDI) as a growth accelerating component has received a great attention in developed countries even in developing and less developed countries during recent years. It has been a matter of greater concern for the economists, how FDI relate to economic growth of the host country's economy. In closed economy there is no access to the foreign instruments and savings, this type of economy solely based on the domestic savings and investment sources. But in open economy, the investment comes from both sources either from domestic savings or foreign capital inflows like FDI. Njeru, Benedict, (2007) reported that a 1\% increase in FDI/GDP leads to a $0.8 \%$ increase in future domestic investment in Africa compared to $1.17 \%$ in Latin America. Many exporting firms are found to locate foreign partners and either form joint ventures with them or hire them as agents for specific technology and/or marketing tasks.

Evidence on the link between FDI and economic growth is inconclusive. Bosworth, Collins, \& Reinhart, (2007), Blomström \& Kokko, (2006), and Obwona, (2001) provide evidence on the positive effects of FDI on economic growth. Growth enhancing effect of FDI is not, however, automatic, but depends on various country specific factors. UNCTAD, (2009), Blomström \& Kokko (2008) et al, and Luiz Jr., (2009) indicate that the positive effect of FDI is stronger the higher the level of development of a host country. Higher level of development allows countries to reap the benefits of productivity fostered by foreign investment. For similar reasons, Gregorio, (2009) et al. have found that significant relations between FDI flows and economic growth depend on the level of human capital. Host countries with better endowment of human capital are believed to benefit more from FDI induced technology transfer as spillover- effects than others with less human capital. Lai, Peng, \& Bao, (2009) tested the effect of FDI on GDP by doing the regression analysis and concluded the results that FDI has positive relationship with GDP and its impact depend upon the absorptive capacity of the host country, level of human capital and development of the financial markets. Iqbal, Ahmad \& Anwar, (2010) conducted a study on the MENA countries to see the impact of FDI on GDP via using econometric model. They come to this conclusion that FDI leads to economic growth but varies according to region and over 
time.

Onakoya, (2010) seeks the impact of FDI on GDP in different sectors of Nigeria country through using threestage least square (3SLQ) technique and Macro Econometric model of simultaneous equation. He found that FDI affect the GDP but significantly cast an impact on the output of that economy. Iqbal, (2010) investigated the relationship of FDI and GDP in Pakistan. Cobb - Douglas Production function was used along with regression equation to draw conclusion from data period of 1971-2009.

He concluded that the effects of Imports substitution and exports oriented economies is different and support the Bhagwati's hypothesis which means FDI's spillover effect in much greater in the latter economy than the former economy. Tran \& Dinh, (2010) do the study in the Vietnam to see the spillover effects of FDI in its economy. Endogenous growth model is used and get the results that there is little evidence of spillover effects of FDI at micro level. Makki \& Somwaru, (2010) seek the impact of FDI on trade and economic growth in 66 developing countries by using cross sectional data. They concluded that FDI interacts positively with trade and FDI promotes domestic investment. It has been also concluded that sound policies and stability are the preconditions for FDI to increase GDP rate. All results are drawn by using econometric model for production function. Mohammad \& Zulkornain, (2012) conducted the study in Malaysia and used time series data from 1970 to 2010. Methodology was based on Toda Yarn Moto test for causality effect on relationship and Bounds testing (ARDL). They draw the conclusion that FDI has indirect effect on GDP.

Noormamode (2013), seek the impact of FDI on economic growth and also studied that host country social and economic conditions matter on FDI spillover effects. A panel VAR model was used and found that there is no clear cut evidence on growth effects of FDI. Khadaroo \& Seetanah, (2014) studied the endogenous relationship between FDI and GDP through panel data of 23 OECD countries for the time series from 1985 to 2010. For this purpose they used two simultaneous equations coupled with generalized methods of moments and draw the conclusion that both factors affect the economy and FDI is the major contributor to accelerate the GDP rate.

Lall (2014), opined that FDI inflow affects many factors in the economy and these factors in turn affect economic growth. This review shows that the debate on the impact of FDI on economic growth is far from being conclusive. The role of FDI seems to be country specific and can be positive, negative or insignificant, depending on the economic, institutional and technological conditions in the recipient countries.

Uma, \& Ezeoke, (2014) explained that FDI plays an extra ordinary and growing role in global business and economics. It can provide a firm with new markets and marketing channels, cheaper production facilities access to new technology products, skills and financing for a host country or the foreign firms with the investment, can provide a source of new technologies, capital processes products, organization technologies and management skills and other positive externalities and spillover that can provide a strong impetus to regional economic growth. Obwona, (2014) noted in his study of the determinants of FDI and their impact on growth in Uganda that macroeconomic and political stability and policy consistency are important parameters determining the inflow of Foreign Direct Investment (FDI) into Uganda and that Foreign Direct Investment (FDI) affects growth positively but insignificant. Foreign Direct Investment (FDI) also contributes to economic growth via technology transfer.

Kosztowniak, (2015) also examined the importance of direct foreign investment in Nigeria. The study empirically examined the impact of FDI on growth. He concluded that FDI contributes significantly to growth especially 
Journal of Economics and Sustainable Development

ISSN 2222-1700 (Paper) ISSN 2222-2855 (Online)

through exports. Hausmann, Hwang, \& Rodrik, (2015) argued that Foreign Direct Investment (FDI) provide a path for emerging nations to export the products developed economies usually sell, in effect increasing their export sophistication.

Many developing countries pursue FDI as a tool for export promotion, rather than production for the domestic economy. Typically foreign investors build plants in nations where they can produce goods for export at lower costs. Herzer, (2015) also found that direct long term impact of Foreign Direct Investment (FDI) on output is significant and positive for comparatively economically less advanced Philippines and Thailand, but negative in the more economically advanced Japan and Taiwan. In the same line, (Mah, 2015) studied the investment trend and its impact on Nigeria's economic growth over the years. He found that only private domestic investment consistently contributed to raising GDP growth rates during the period considered (1970-2014). However, Alfaro\& Sayek (2015) affirmed that the contribution of FDI to growth depends on the sector of the economy where the FDI operates. He claimed that FDI inflow to the primary sectors tends to have a negative effect on growth, however, as for the service sector, the effect of FDI inflow is not so clear. Durham, (2016) for example, failed to establish a positive relationship between Foreign Direct Investment (FDI) and growth but instead suggests that the effects of Foreign Direct Investment (FDI) are contingents on the absorptive capability of host countries.

Using univariate and panel co-integration for 1970- 2015, (Pradhan, 20015) study the relationship between foreign direct investment (FDI) and economic growth in the five ASEAN countries namely: Indonesia, Malaysia, Philippines, Singapore and Thailand results reports evidence of positive relationship between FDI and economic growth at both panel and individual level for the countries though with exemption of Indonesia, Malaysia and Philippines at individual level. However, when Granger causality test was done and results show evidence of bidirectional causality both at individual and panel level with exception of Malaysia.

\section{Foreign Direct Investment and Economic Growth}

The main idea underlying the FDI liberalization policies of many developing countries and the FDI promotion efforts of international donors such as the World Bank and the IMF is the notion that FDI inflows foster economic growth. As FDI is a composite bundle of capital stocks, know- how, and technology, its impact on economic growth is expected to be manifold (De Mello, 1997; Dunning, 1992). In the ways through which FDI can affect economic growth we can distinguish direct and indirect effects.

Theoretical arguments assign a key role for FDI in economic growth. While these theoretical arguments are quite straightforward and widely accepted, the empirical evidence is much more ambiguous, or as (Guerra, de Lara, Malizia, \& Díaz, 2009) puts it: "whether FDI can be deemed to be a catalyst for output growth, capital accumulation, and technological progress, seems to be a less controversial hypothesis in theory than in practice". The empirical macro - economic literature shows a clear link between FDI and GDP growth but the direction of causality is not always clear (Chakraborty \& Nunnenkamp, 2008). Also when the heterogeneity of the host economies is recognized in empirical studies, the link between FDI inflows and growth becomes ambiguous (Samadhan, 2013). 
Journal of Economics and Sustainable Development

ISSN 2222-1700 (Paper) ISSN 2222-2855 (Online)

\section{Foreign Direct Investment and Economic Growth in Nigeria}

In the Federal Republic of Nigeria, foreign direct investment (FDI) is defined as investment undertaken by an enterprise that is either wholly or partly foreign-owned. The Investment Code that created the Nigerian Investment Promotion Commission (Decree No. 16 of 16th January 1995) and the Foreign Exchange (Monitoring and Miscellaneous Provision) also enacted in 1995 give full legal backing for FDI in the country (UNCTAD, 2006).

Before 1970s, Nigerian foreign direct investment was mainly on agricultural products and raw materials. According to UNCTAD report (2009), the foreign direct investment in the oil sector amounted to only ten percent of total inflows in the early nineteen seventies. This simply means that FDI inflows were mainly focused in the commercial sector, making exportation of agricultural product favorable. Today, foreign direct investment focuses more on the oil sector. Majority of the investors in the Nigerian business environment had been from those countries where the oil barons had originated from. For example, The Royal Dutch Company Shell from the Netherlands, Total Oil from France and ENI from Italy as well as Exxon Mobil, Texaco and Chevron form the United States of America (UNCTAD, 2009).

Foreign Direct Investment (FDI) is often seen as an important catalyst for economic growth in the developing countries because it affects the economic growth by stimulating domestic investment, increase in capital formation and also, facilitating the technology transfer in the host countries. Ogunleye, (2014) as cited in Aremu2003, observes that foreign firms can raise the level of capital formation, promote exports and generate foreign exchange. Indeed, the role of FDI in capital formation in Nigeria has been increasing over the years. It is widely believed that economic growth depends critically on several factors. Notably it must be said that economic growth is reliant on both domestic and foreign investments (Onu, 2012). Equally, economic growth is the basic determinant of the rate of inflow of foreign direct investment in the country. Onu, (2015) cited in Aremu(2004), attempt to establish a better relationship between investment and growth in Nigeria. FDI stimulates product diversification through investments into new businesses, stimulates employment generation, increase wages and accelerate declining market sectors of the host economies (Aremu, 2014).

One of the major economic problems of any developing and underdeveloped countries is inadequate savings. Inadequate domestic savings or inappropriate mobilization of savings for investment purposes is what is termed in the literature as savings constraint (saving-gap). This gap can be corrected by encouraging the foreign direct investment (FDI) otherwise known as foreign capital inflow. The major focus of this section is to indicate the effect of FDI on economic growth in Nigeria. Attracting foreign direct investment would tend to improve economic conditions while its volatility can trigger macroeconomic instability in the country, especially Nigeria. From the literature, FDI is an investment made to acquire a lasting management interest (normally $10 \%$ of voting stock) in a business enterprise operating in a country other than that of the investor as defined by the residency (World Bank, 2011). One of the purposes for which the New Partnership for Africa's development (UNAIDS and NEPAD, 2012) was established is to encourage the inflow of FDI inform of new technology, refined marketing strategy and management.

\section{Transmission Mechanisms Between FDI and Economic Growth}

Through initial macroeconomic stimulus, FDI is thought to contribute to economic growth and development, 
by raising total factor productivity and efficiency of resource use in the host economy through transfer of more advanced technology and organizational forms directly to Multi-National Companies (MNC) affiliates in the host country. In addition, FDI could also trigger technological and other spillovers to locally owned enterprises, assisting human capital formation, contributing to international trade integration, helping to create a more competitive business environment, enhancing enterprise development and general improvement in environmental and social conditions of the host country (Blomstrom, Kokko, \& Kokko, 2004 et al, Ikiara, 2003). As illustrated, these transmission mechanisms could ultimately lead to higher economic growth, which is the most potent tool for poverty reduction in developing countries. That notwithstanding, it is often believed that growth is not a sufficient condition for poverty alleviation, since, there is evidence that higher incomes in developing countries benefit the poor segments of the population proportionately (Tang, 2012).

According to neoclassical theory, FDI influences income growth by increasing the amount of capital per person, but does not influence long-run economic growth due to diminishing returns to capital; in addition, recent endogenous growth theorists (e.g Romer, 1986, 1990 and Lucas, 1988), argue that FDI spurs longrun growth through such variables as research and development $(R \& D)$ and human capital. They suggest that, through technology transfer to both affiliates and unaffiliated firms in the host economy, MNCs can speed up the development of new intermediate product varieties, raise product quality, facilitate international collaboration on $\mathrm{R} \& \mathrm{D}$, as well as, introduction of new forms of human capital. However, in a deviation from many studies, few empirical studies, especially those using firm-level data, observed insignificant impact of FDI on economic growth and that FDI is no more productive than domestic investments (Kumar, 1996). Nevertheless, by controlling for simultaneity bias, country-specific effects, and proper use of lagged dependent variables in growth regressions, Carkovic and Levine (2002) observed positive impacts. Some of the studies showed marginal macroeconomic impacts, with FDI actually crowding out local investments and other types of foreign flows in some countries, and adversely affecting their current accounts (Ikiara, 2003).

\section{Determinants of Foreign Direct Investment (FDI)}

The issue of determinants of foreign direct investment is somehow difficult to understand and generalize because the nature of businesses differ with their different requirements so it is of great assignment for the foreign investors to find a better environment suitable for their investments. But generally, it can be agreed upon that, those factors suitable for domestic investments could be of great importance to foreign investments as such as political, economic, social and cultural and geographical location of the country. These suggested factors that could enhance the inflow of FDI generally could be listed and explained as follow:

Infrastructure: poor infrastructure is one of the main hindrance and obstacles of the FDI inflow in any country and good infrastructural facilities will sure make a nation more attractive to foreign investors as well improve the qualities of the domestic investment. Infrastructure covers many dimensions, ranging from roads, ports, railways, and telecommunication systems to institutional development like accounting, legal services (Ajayi, 2006).

Labour Cost: the idea of investing in the developing countries is considering advantageous due to the low labour cost and wages. According to (Wellhausen, 2013), all other factors remaining unchanged, lower labor cost reduces the cost of production, but the availability of cheap labor justifies the relocation of a part of the 
production process in foreign countries.

Resources: availability of natural resources is of great interest to any nation domestically and also to bring the foreign investors into the country. Africa had the influence of FDI basically because of the presence of resource in the region. Traditionally, about $60 \%$ of Africa's FDI is allocated to oil and natural resources (UNCTAD, 2013). The rising profits in the sector induced a flow of investment.

Political factor: this has to do with the abnormal changing of leaders, governmental policies, and security issues to government, and regime type. The stability of political administration of a nation is of great significant to the operation of a multinational companies.

Privatization: some foreign investors can be attracted by privatization and this took place in some countries like Ghana in 1995 and Nigeria in 1992. This has to do with the fact that, some governmental companies are taken over by the private individual, which could lead to competition among the private ownership of productions.

\section{The Methodology of the Study}

A methodological research approach and design is a framework that binds research together so that the research questions can be analyzed effectively (Edmondson \& McManus, 2007). The relationship between FDI and Economic Growth in Nigeria will be analyzed through a quantitative research method which will entail the generation of data in quantitative form which will then be subjected to rigorous quantitative. The source of data for this study is secondary obtained from the Central Bank of Nigeria statistical bulletins and annual reports, the National Bureau of Statistics [NBS], and other cognate publications. The main tool of analysis is a simple unrestricted Vector Autoregressive (VAR) model. Itwill estimated and evaluated for statistical fit to explore the dynamic linkage between FDI and GDP in Nigeria. The VAR model provides a multivariate framework where changes in a particular variable (FDI) are related to changes in its own lags and to changes in other variables and the lags of those variables.

\section{Model Specification}

Consider a VAR model of the order $\mathrm{p}$ :

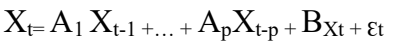

Assume the vector: $\mathrm{x}=\mathrm{f}(F D I, H C A P, G C F, E X R, D I N V, D S A V)$, where $\mathrm{FDI}=$ Direct foreign investment, $\mathrm{GCF}=$ Gross Capital Formation, DINV=Domestic Investment, EXR=Exchange Rate and HCAP=Human Capital, DSAV=Real Domestic Saving)

Assume that the vector has a VAR representation of the form:

$$
X_{t}=z+\sum_{i=1}^{p} \Pi_{i} X_{t-1}+\varepsilon_{t}
$$

Where $\mathrm{z}$ is a $(\mathrm{n} \times 1)$ vector of deterministic variables, $\varepsilon$ is a $(\mathrm{n} \times 1)$ vector of white noise error terms and $\Pi$ is $(\mathrm{n} \times \mathrm{n})$ matrix of coefficients.

Where $\mathrm{X}_{t}$ is a vector of $\mathrm{I}(1)$ variables,$\Delta \mathrm{X}_{\mathrm{t}}$ are all $\mathrm{I}(0)$ variables, $\Delta$ indicates the first difference operator, $\mathrm{B}$ is a $(n \times n)$ coefficient matrix and $\Pi$ is a $(n \times n)$ matrix whose rank determines the number of cointegrating relationships. The Johansen test is to estimate the rank of $\Pi$ matrix ( $r$ ) from an unrestricted VAR and to test 
Journal of Economics and Sustainable Development

ISSN 2222-1700 (Paper) ISSN 2222-2855 (Online)

whether we can reject the restrictions implied by the reduced rank of $\Pi$.

\section{Empirical Result}

This section presents results of empirical analyses of the study. Unit root is first conducted, then followed by Johansen co-integration result and lastly vector autoregressive (VAR). In this section, we present the empirical results on the impact of foreign direct investment on the Nigerian economy. In order to determine whether the macro variables are stationary or otherwise, unit root tests are conducted if non-stationary at levels, we then go ahead to determine the order of integration. Next a test of co-integration is carried out between all the variables of the study. Test for the stationary of the variables are presented in table 1 below.

The ADF test here consists of estimating the following regression:

$$
\Delta Y_{t}=\beta_{1}+\beta_{2 t}+\delta Y_{t-1}+\sum_{i=1}^{m}+\alpha i \Delta Y_{t-1}+\varepsilon_{t}
$$

Where $\varepsilon t$ is a pure white noise error term, $t$ is the time or trend variable and where $\Delta Y_{t-1}=\left(Y_{t-1}-Y_{t-2}\right)$, $\Delta \mathrm{Y}_{\mathrm{t}-2}=\left(\mathrm{Y}_{\mathrm{t}-2}-\mathrm{Y}_{\mathrm{t}-3}\right)$, etc. The number of lagged difference terms to include is often determined empirically, the idea being to include enough terms so that the error term in Eq. (vi) is serially uncorrelated, so that we can obtain an unbiased estimate of $\delta$, the coefficient of lagged $Y_{t-1}$.

The test results suggest that the null hypothesis of unit root for the five time series namely, real gross domestic product (RGDP), foreign direct investment (FDI), gross capital formation (GCF), domestic savings (DSAV) and domestic investment (DINV) cannot be rejected at levels. This prompted us to test the Augmented Dickey-Fuller (ADF) test at first levels. The result as shown in table1 suggests that the null hypothesis of the variables can be rejected in the first difference. These shows that some of the variables are stationary at first difference and are integrated of order one or are 1(1) series while some are stationary at order 2.

Table 1: Augmented Dickey Fuller Test

\begin{tabular}{|c|c|c|c|c|c|c|}
\hline \multirow{3}{*}{ Variables } & \multirow{3}{*}{$\begin{array}{c}\text { Order of } \\
\text { integration }\end{array}$} & \multicolumn{4}{|c|}{ Augmented Dickey Fuller } & \multirow{3}{*}{ Prob. } \\
\hline & & \multicolumn{3}{|c|}{ ADF tests Critical Values } & \multirow[t]{2}{*}{$\begin{array}{c}\text { ADF } \\
\text { Statistic }\end{array}$} & \\
\hline & & $1 \%$ & $5 \%$ & $10 \%$ & & \\
\hline$\Delta$ RGDP & $\mathrm{I}(1)$ & 3.689194 & 2.71853 & 2.625121 & 3.759971 & 0.0005 \\
\hline$\Delta$ FDI & $\mathrm{I}(1)$ & 3.646342 & 2.95021 & 2.615817 & 7.438557 & 0.0000 \\
\hline$\Delta \mathbf{G C F}$ & $\mathrm{I}(2)$ & 4.35542 & 3.75213 & 2.615817 & 6.020961 & 0.0000 \\
\hline$\triangle \mathrm{DSAV}$ & $\mathrm{I}(1)$ & 3.646342 & 2.95021 & 2.615817 & 5.966006 & 0.0000 \\
\hline$\Delta \mathrm{DINV}$ & $\mathrm{I}(1)$ & 3.646342 & 2.95021 & 2.615817 & 5.966006 & 0.0050 \\
\hline
\end{tabular}

1. $\Delta=$ Difference Operator, 2. I(d) $=$ No. of times of integration 3. Level $=10 \%, 5 \%$ and $1 \%$ level of significance Source; Author's estimation using E-view 9.0 
For the ADF statistics, the $99 \%, 95 \%$, and $90 \%$ critical values are shown after each T-statistics on table 1 . The result above shows that none of the variables were stationary at levels. This can be seen by comparing the observed values (in absolute terms) of the ADF test statistics at 1\%, 5\% and 10\% levels of significance. The result provides some evidence that non- of the variables were stationary when differenced at levels, hence there is evidence of non-stationary. However, differencing once induced stationary in four (RGDP, DINV, DSAV and FDI) while gross capital formation (GCF) was differenced twice to attain stationary. Therefore, the null hypothesis is accepted for non-stationary for the variables at levels and it is sufficient to conclude that there is a presence of unit root at levels. On these bases, the null hypothesis of non-stationary is rejected for all the variables and we therefore, conclude the variables are stationary. This further implies that the variables are integrated of order one, I (1) and two I (2).

\section{Test Result for Co integration}

After forming the stationary of the variables, we proceed to test for the co integration among the variables. When co integration is present, it means that economic growth, inflation rate, balance of payment and money supply share a common trend and long-run equilibrium as suggested in theory. We started the co integration analysis by employing the Johansen and Juselius multivariate co integration test.

Johansen's methodology takes its starting point in the vector auto-regression (VAR) of order p given by

$$
\Delta Y_{t}=\mu+A_{1} y_{t-1}+\cdots+A_{p} y_{t-p}+e_{t}
$$

Where Yt is an $n x 1$ vector of variables that are integrated of order one - commonly denoted I(1) - and $\varepsilon t$ is an $\mathrm{nx} 1$ vector of innovations. This VAR can be re-written as:

$\Delta Y_{t}=\mu+\Pi y_{t-1}+\sum_{j-1}^{p-1} \Gamma j \Delta y_{t-j}+e_{z}$

The maximum Eigen value statistics indicated (4) co integrating vectors at the 5 percent level of significance, suggesting that there is co integration relation between monetary police and the different measures of macroeconomic stability.

Table1c Co-Integration Test

Series: RGDP FDI GCF DSAV DINV

Lags interval: 1 to 1

\begin{tabular}{ccccc}
\hline \hline Eigenvalue & $\begin{array}{c}\text { Likelihood } \\
\text { Ratio }\end{array}$ & $\begin{array}{c}\text { 5 Percent } \\
\text { Critical Value }\end{array}$ & $\begin{array}{c}\text { 1 Percent } \\
\text { Critical Value }\end{array}$ & $\begin{array}{c}\text { Hypothesized } \\
\text { No. of CE(s) }\end{array}$ \\
\hline \hline 0.935594 & 213.3558 & 94.15 & 103.18 & None ** \\
0.899440 & 144.7921 & 68.52 & 76.07 & At most $1 * *$ \\
0.836302 & 87.36713 & 47.21 & 54.46 & At most $2 * *$
\end{tabular}

Source: Author's estimation using E-view 9.0 


\section{VAR MODEL ESTIMATES}

\section{i. Impulse Response Function}

The impulse response function examines the response of the dependent variable in the VAR to shocks in the error terms. (Asteriou and Stephen, 2007). It thus traces the effect of a shock emanating from an endogenous variable to other variables through the dynamic structure of the VAR. A generalized impulse response function is used to show the influence of changes in FDI, GCF, DINV, and DSAV on economic growth in Nigeria. The impulse responses are illustrated in figure 1. Under the generalized impulse response causal ordering of the variables doesn't matter. The generalized impulse response shows how long and by what extent Economic growth reacts to unanticipated changes in FDI, GCF, DINV, DSAV, and DSAV. The horizontal axis measures the years after the impulse shock and the vertical axis measure the magnitude of the response.

\section{Figure 3: Impulse Response}
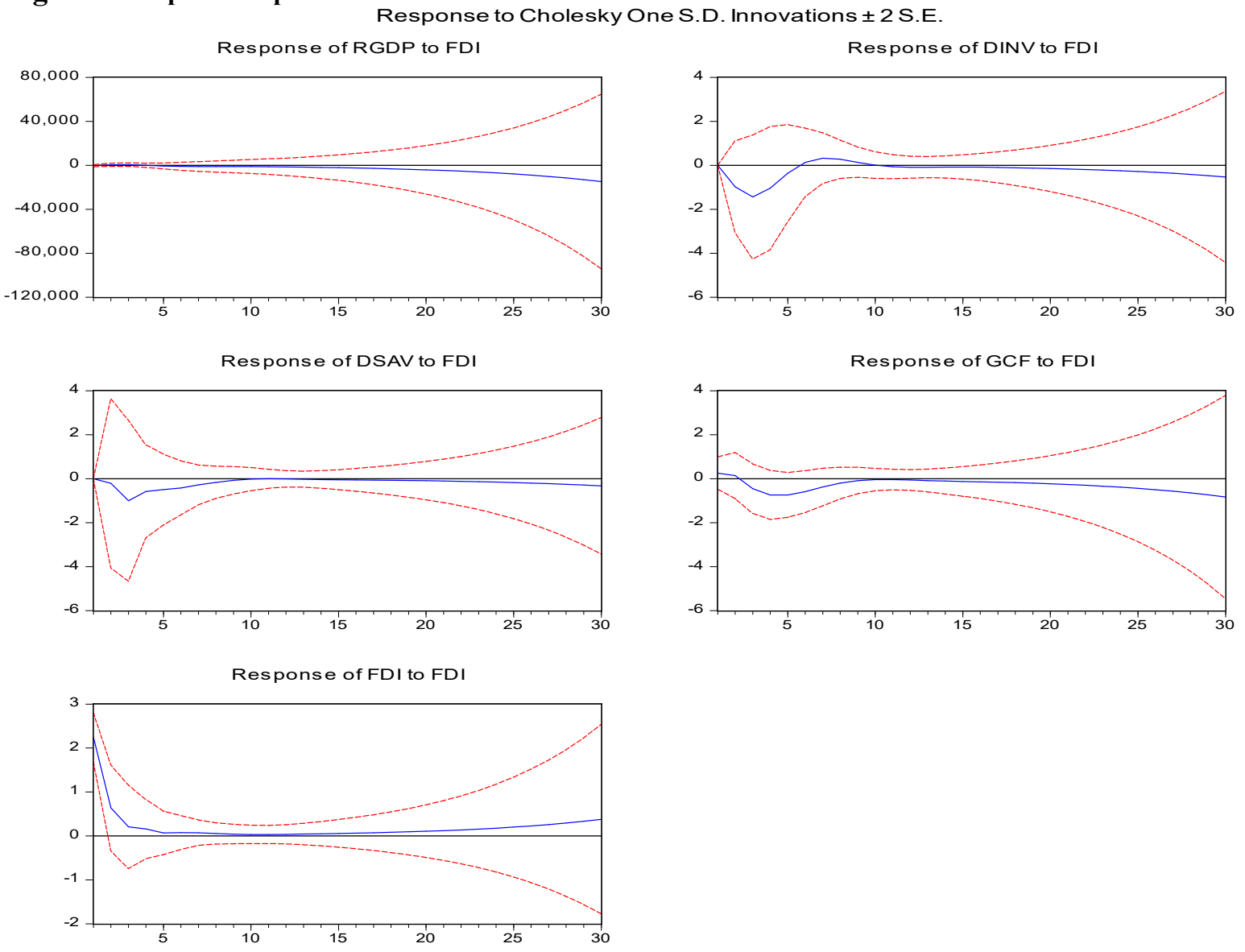

Figure 1 above reveals that a response shock in FDI has a negative impact on economic growth in Nigeria in the $1^{\text {st }}$ period and declining gently to zero in the $2^{\text {nd }}$ period and thereafter becomes negative in the $9^{\text {th }}$ period, maintains a stable path up to the $20^{\text {th }}$ period and dampens down gradually to the end of the $30^{\text {th }}$ period. The own shocks of FDI exerts positive effect in the $1^{\text {st }}$ period up to the $15^{\text {th }}$ period, then declines to zero and maintains a gentle stable path up to the $30^{\text {th }}$ period. The shock from FDI on GCF is positive in the $1^{\text {st }}, 2^{\text {nd }}$ and $3^{\text {rd }}$ but dies off and becomes 
negative after the $30^{\text {th }}$ period. However, DSAV responds positively to a shock in FDI in the $1^{\text {st }}$ period, becomes negative in the $2^{\text {nd }}$ period and thereafter rising up and becomes zero in $20^{\text {th }}$ period and also maintains a very gentle stable slope till after $30^{\text {th }}$ period. Finally, the shocks from FDI on DINV is positive in the $1^{\text {st }}$ period, becomes negative in the $2^{\text {nd }}$ period and then rises up and becomes zero in the $13^{\text {th }}$ period and gradually becomes positive after $18^{\text {th }}$ period and then rises gently until after $30^{\text {th }}$ period.

\section{Summary of Findings}

The VAR analyses reveal that the impulse response function shows how important RGDP is in affecting FDI beyond the sample period. Thus, this implies that in order to sustain high economic growth in the long-run, the country needs to increase the efficiency of its workable investment fund and expand its saving capacity to generate more capital.

This result is also in agreement with the study, Feridun and Sissoko (2006) examines the relationship between FDI and economic growth for the period 1976 to 2002 in Singapore using Granger causality and vector auto regression (VAR). Their findings revealed a unidirectional causation running from FDI to economic growth. It is also consistent with Bornschier and Hoby (1981) and Dolan and Tomlin (1980) who find that FDI flows were positively associated with growth of per capita incomes.

The results also emphasize the need for the government to weed out deep rooted vices such as corruption, reinforce security especially in the wake of terror attacks (Boko Haram, Niger-Delta Militants, among others). Based on the above, we need to enhance more gross capital formation in order to promote economic growth. Policy implications of these findings are that GCF is a prerequisite for economic growth in Nigeria. The results also emphasize the need to invest in human development since growth in the GDP would be immaterial if the same does not reflect positively on the populace by translating to improved living standard.

\section{Conclusions}

Nigeria has comparatively low levels of FDI and as such needs to improve its business environment by ensuring that administrative procedure, legal and judiciary system are improved so as to ensure property

right, fight corruption and respect rule of law and due processes. All of these will see higher levels of much needed FDI channeled into the country.

One of the major problems of developing nation is the need or requirement of domestic savings for investment. The saving gap in such countries can be corrected by the FDI. There are attendant benefits of FDI to a host country like Nigeria, such as productivity gains, technological, transfers, introduction of new processes, management skill and know-how, employee training, employment opportunities etc. FDI affects economic growth by stimulating domestic investment, increased capital formation, stimulates product diversification through investment into new business and subsequently promote exports and generate foreign exchange.

Eventually this will translate into increased output and have economic growth.

There is therefore the need by countries such as Nigeria for the policy makers to attract FDI since effects of FDI are contingents of the host country's abortive capacity. Availability of human capital, macro-economic and political stability and policy consistency are important determinants/parameters determining the inflow of FDI into 
Journal of Economics and Sustainable Development

ISSN 2222-1700 (Paper) ISSN 2222-2855 (Online)

a country.

Therefore, government needs to go a step further and actively seek to attract FDI by marketing our economy and setting up national investment promotion agencies. Nigeria should adopt a proactive approach towards FDI promotion, and explicitly look for ways to increase its benefits in terms of technology, skills and market access.

\section{References}

Abubakar, A., Kassim, S. H., \& Yusoff, M. B. (2015). Financial Development, Human Capital Accumulation and Economic Growth: Empirical Evidence from the Economic Community of West African States (ECOWAS). Procedia - Social and Behavioral Sciences, 172, 96-103. http://doi.org/10.1016/j.sbspro.2015.01.341

Adofu, \& Ilemona. (2010). Accelerating Economic Growth in Nigeria, the Role of Foreign Direct Investment: A Re-assessment. Current Research Journal of Economic Theory, 2(1), 11-15. Retrieved from http://maxwellsci.com/print/crjet/v2-11-15.pdf/nhttp://www.maxwellsci.com/print/crjet/v5-71-81.pdf

Alfaro, L., Chanda, A., Kalemli-Ozcan, S., \& Sayek, S. (2010). Does foreign direct investment promote growth? Exploring the role of financial markets on linkages. Journal of Development Economics, 91(2), 242-256. http://doi.org/10.1016/j.jdeveco.2009.09.004

Azman-Saini, W. N. W., Baharumshah, A. Z., \& Law, S. H. (2010). Foreign direct investment, economic freedom and economic growth: International evidence. Economic Modelling, 27(5), 1079-1089. http://doi.org/10.1016/j.econmod.2010.04.001

Babatunde, A. F. (2011). Financial Development, Foreign Direct Investment and Economic Growth: Challenges for Developing Countries being, 397.

Chia, S. H. and, \& Ogbaji, E. O. (2013). Impact of Foreign Direct Investment on Telecommunication Sector on Nigerian Economy. International Journal of Modern Social Sciences, 2(3), 195-215. http://doi.org/10.6007/IJARAFMS/v5-i1/1503

Durham, J. B. (2004). Absorptive capacity and the effects of foreign direct investment and equity foreign portfolio investment on economic growth. European Economic Review, 48(2), 285-306. http://doi.org/10.1016/S0014-2921(02)00264-7

Franco, C. (2013). Exports and FDI motivations: Empirical evidence from U.S. foreign subsidiaries. International Business Review, 22(1), 47-62. http://doi.org/10.1016/j.ibusrev.2012.02.002

Grossman, G. M., \& Helpman, E. (1991). Innovation and Growth in the Global Economy. booksgooglecom (Vol. 124). http://doi.org/10.2307/2554862

Guerra, E., de Lara, J., Malizia, A., \& Díaz, P. (2009). Supporting user-oriented analysis for multi-view domainspecific visual languages. Information and Software Technology.

Herzer, D. (2008). The long-run relationship between outward FDI and domestic output: Evidence from panel data. Economics Letters, 100(1), 146-149. http://doi.org/10.1016/j.econlet.2007.12.004

Ikiara, M. M. (2003). Foreign Direct Investment (FDI), Technology Transfer, and Poverty Alleviation : Africa ' 
Journal of Economics and Sustainable Development

ISSN 2222-1700 (Paper) ISSN 2222-2855 (Online)

s Hopes and Dilemma.

Iqbal, Z. (2015). An Econometric Analysis of Foreign Direct Investment and Economic Growth of Pakistan, 5(11), $16-26$.

Khadaroo, A. J., \& Seetanah, B. (2010). Transport Infrastructure and Foreign Direct Investment. Journal of International Development, 22, 103-123. http://doi.org/http://dx.doi.org/10.1002/jid.1506

Kosztowniak, A. (2013). Foreign Direct Investment as a Factor of Economic Growth in Poland . Empirical Analysis for the Period, 1(2), 203-212. http://doi.org/10.13189/aeb.2013.010215

Lucas, R. E. (1988). On the mechanics of economic development. Journal of Monetary Economics, 22(1), 3-42. http://doi.org/10.1016/0304-3932(88)90168-7

Luiz Jr., R. D. M. (1997). Foreign direct investment in developing countries and growth: A selective survey. The Journal of Development Studies, 34(1), 1. Retrieved from http://proquest.umi.com/pqdweb?did=23216773\&Fmt=7\&clientId=25620\&RQT=309\&VName=PQD

Mah, J. S. (2010). Foreign direct investment inflows and economic growth of China. Journal of Policy Modeling, 32, 155-158. http://doi.org/10.1016/j.jpolmod.2009.09.001

Makki, S. S., \& Somwaru, A. (2004). Impact of Foreign Direct Investment and Trade on Economic Growth: Evidence from Developing Countries. American Journal of Agricultural Economics, 86(3), 795-801. http://doi.org/10.1111/j.0002-9092.2004.00627.x

Mankiw, G. (2010). Principles of Macroeconomics. Business. http://doi.org/10.1017/CBO9780511894572.014

Obwona, M. B. (2001). Determinants of FDI and their Impact on Economic Growth in Uganda. African Development Review, 13(1), 46-81. http://doi.org/10.1111/1467-8268.00030

Ogunleye, O. (2014). The Effect Of Foreign Direct Investment : Case Study Nigeria Master “s Thesis Department of International Business May 2014 Abstract Of The Master ” S Thesis Department of International Business Ogunleye Oyin Petri Ahokangas ( Professor, D, (May), 1-62.

Okpara, G. (2010). Stock market prices and the random walk hypothesis: Further evidence from Nigeria. Journal of Economics and International Finance, 2(3), 49-57.

Onu, A. J. C. (2012). Impact of Foreign Direct Investment on Economic Growth in Nigeria, 64-79.

Osinubi, T. S., \& Amaghionyeodiwe, L. A. (2010). Foreign Private Investment And Economic Growth In Nigeria. Review of Economic \& Business Studies, 3(1), 105-127.

Oyeranti, G. A., Babatunde, M. A., \& Ogunkola, E. O. (2011). An analysis of China-Nigeria investment relations. Journal of Chinese Economic and Foreign Trade Studies, 4(3), 183-199. http://doi.org/10.1108/17544401111178221

Patricia, N., \& Izuchukwu, D. (2013). Impact of Government Expenditure on Economic Growth in Nigeria. International Journal of Business and Management Review, 1(4), 64-71.

Romer, P. M. (1986). Increasing returns and long-run growth. The Journal of Political Economy, 94(5), 10021037. http://doi.org/10.1086/261420 
Journal of Economics and Sustainable Development

ISSN 2222-1700 (Paper) ISSN 2222-2855 (Online)

Solow, R. M. (1956). A contribution to the theory of economic growth. The Quarterly Journal of Economics, 70(1), 65-94. http://doi.org/10.2307/1884513

Uma, K. E., Odionye, J. C., Aniagolu, H. N., \& Ezeoke, C. (2014). An Investigation Of The Effects Of Investment And Savings In Nigeria Economy.

Umoh, O., Jacob, A., \& Chuku, C. (2012). Foreign Direct Investment and Economic Growth in Nigeria: An Analysis of the Endogenous Effects. Current Research Journal of Economic Theory, 4(3), 53-66. Retrieved from

http://scholar.google.com/scholar?hl=en\&btnG=Search\&q=intitle:Foreign+Direct+Investment+and+Econ omic + Growth+in+Nigeria+:+An+Analysis + of + the+Endogenous + Effects $\# 0$

UNAIDS and NEPAD. (2012). Memorandum of understanding between NEPAD and UNAIDS. Aids.

UNCTAD. (1997). World investment report, 1997: Transnational corporations, market structure and competition policy. New York.

UNCTAD. (2012). World Investment Report 2012: Towards a New Generation of Investment Policies. World Investment Report, (July), 1-41.

UNCTAD. (2013). Wake up before it is too late. Make agriculture truly sustainable now for food security in a changing climate. Trade and Environment Review 2013.

UNIDO. (2002). Industrial Development Report 2002-03 (Vol. 12). http://doi.org/10.1039/b917653e

Wellhausen, R. L. (2013). Innovation in tow: R\&D FDI and investment incentives. Business and Politics, 15(Johnson 2011), 467-491. http://doi.org/10.1515/bap-2013-0014

AUTHOR: Damina Hamid Babawulle was born in Liman Katagum in Bauchi State, Nigeria on 15 ${ }^{\text {th }}$ July, 1960. Obtained B.Sc Economics in 1983 from University of Maiduguri in Nigeria, Masters in Business Administration from Modibbo Adama University, Yola, Nigeria. Have worked with Bauchi State Government and was in banking for years before coming back to academics from 2013 to date. Area of specialization is in Monetary Economics. 